\title{
Physiological Responses of Chickpea (Cicer arietinum L.) Genotypes to Salinity Stress
}

\author{
Dharamvir*, Ajeev Kumar, Neeraj Kumar and Mahesh Kumar \\ Department of Botany and Plant Physiology, CCS Haryana Agricultural University, \\ Hisar-125 004, Haryana, India \\ *Corresponding author
}

\section{Keywords}

Cicer arietinum, Osmotic potential, Proline, Total soluble carbohydrates,

Water potential

Article Info

Accepted:

18 October 2018

Available Online:

10 November 2018

\section{A B S T R A C T}

Plant growth and development are adversely affected by salinity- a major environmental stress that limits agricultural production. Chickpea (Cicer arietinum L.) is sensitive to salinity that affects its yield and there is need to identify the tolerant genotypes. In order to evaluate the effect of soil salinity, a pot experiment with two chickpea genotypes was carried out under screen house conditions. The required amounts of chloride and sulphate salts of $\mathrm{Na}^{+}, \mathrm{Ca}^{+2}$ and $\mathrm{Mg}^{+2}$ were added through $\mathrm{NaCl}, \mathrm{Na}_{2} \mathrm{SO}_{4}, \mathrm{CaCl}_{2}, \mathrm{MgCl}_{2}$ and $\mathrm{MgSO}_{4}$. Sodium and $\mathrm{Ca}^{+2}+\mathrm{Mg}^{+2}$ were in the ratio of $1: 1$ where $\mathrm{Ca}^{+2}$ and $\mathrm{Mg}^{+2}$ were in the ratio of $1: 3$ to develop three $(2.0,4.0$, $6.0 \mathrm{dS} \mathrm{m}^{-1}$ ) levels of saline soil before sowing. The control plants were irrigated with distilled water. Sampling was done at 50-60 days after sowing. The water potential $\left(\Psi_{\mathrm{w}}\right)$ of leaves, osmotic potential $\left(\Psi_{\mathrm{s}}\right)$ of leaves and roots decreased significantly in both the genotypes under different salinity levels. HC-3 showed more negative values of $\Psi_{\mathrm{w}}$ of leaves i.e. from -0.47 to $0.54 \mathrm{MPa}$ as compared to -0.45 to $-0.51 \mathrm{MPa}$ in CSG-8962, respectively with increasing salinity level from control to $6.0 \mathrm{dS} \mathrm{m}^{-1}$. Likewise, the $\Psi_{\mathrm{s}}$ of leaves decreased from -0.75 to 1.32 MPa in HC-3 and -0.62 MPa to $-1.18 \mathrm{MPa}$ in CSG-8962. With increase in salinity levels, RWC (\%) of leaves and roots also declined in both the genotypes. RWC was higher in HC-3 than CSG-8962. The chlorophyll a, chlorophyll b and carotenoid concentration of chickpea genotypes also showed significant reduction under salinity stress as compared to controls. Reduction in photosynthetic pigments was more in CSG-8962 than HC-3. The proline content of leaves increased significantly from 0.573 to 0.904 and 0.565 to $0.782 \mathrm{mg} \mathrm{g}^{-1}$ dry weight and the total soluble carbohydrate (TSC) from 17.5 to 24.5 and 16.60 to $20.3 \mathrm{mg} \mathrm{g}^{-1}$ dry weight in HC-3 and CSG-8962, respectively with increasing level of salinity from control to $6.0 \mathrm{dS} \mathrm{m}^{-1}$. Salinity levels increased the $\mathrm{Cl}^{-}$concentration in leaves by $93.3 \%$ in $\mathrm{HC}-3$ and $120.1 \%$ in CSG-8962, and $\mathrm{SO}_{4}{ }^{2-}$ by $11.1 \%$ in $\mathrm{HC}-3$ and $19.7 \%$ in CSG-8962 at $6.0 \mathrm{dS} \mathrm{m}^{-1}$ salinity levels as compared to their respective controls. The genotype $\mathrm{HC}-3$ had overall lower accumulation of $\mathrm{Cl}^{-}$and $\mathrm{SO}_{4}{ }^{2-}$ than the CSG-8962.More negative values of $\Psi_{\mathrm{w}}$ of leaves, $\Psi_{\mathrm{s}}$ of leaves and roots and better accumulation of osmotically active solutes, i.e. proline and TSC of HC-3, helped in maintaining the higher RWC of these organs than noticed in CSG-8962. The number of branches plant ${ }^{-1}$, number of pods plant ${ }^{-1}$, number of seeds pod $^{-1}$, test weight and seed yield plant ${ }^{-1}$ reduced in both the genotypes with increasing level of salinity from control to $6.0 \mathrm{dS} \mathrm{m}^{-1}$. The reduction is more in CSG-8962 as compared to HC-3. Hence, the mechanism of salt tolerance is relatively better in HC-3 than in CSG-8962 as found from physiological and yield attributes studied and could be used in crop improvement programme of chickpea for salinity tolerance. 


\section{Introduction}

Chickpea (Cicer arietinum Linnaeus), a member of family Fabaceae, is an ancient selfpollinated leguminous crop, diploid annual ( $2 \mathrm{~N}=16$ chromosomes) grown since $7000 \mathrm{BC}$, in different area of the world (Tekeoglu et al., 2000) but its cultivation is mainly concentrated in arid and semi-arid environments such South Asia, West Asia, North Africa, East Africa, Southern Europe, North and South America, and Australia (Arefian et al., 2014; Flowers et al., 2010). In India, Madhya Pradesh, Rajasthan, Maharashtra, Uttar Pradesh, Andhra Pradesh, Karnataka, Chhattisgarh, Bihar and Jharkhand are major chickpea producing states contributing more than $95 \%$ to the total chickpea production. Madhya Pradesh is the single largest producer in the country accounting for over $40 \%$ of total production while Rajasthan, Maharashtra, Uttar Pradesh and Andhra Pradesh contribute about 14\%, $10 \%, 9 \%$ and $7 \%$, respectively.

The share of Andhra Pradesh and Karnataka has consistently been rising during the past one decade. Further, states like Jharkhand and Chhattisgarh are expanding their area and production of chickpea crop (AICRP, 201415). The chickpea seed is a valuable source of carbohydrates and proteins, which together constitute $80 \%$ of the total dry seed weight. The crude protein content of chickpea varies from $17 \%$ to $24 \%$ containing the essential amino acids like tryptophan, methionine and cysteine (Williams and Singh, 1987). Thus, chickpea serves as a main source of dietary protein for more than $80 \%$ of the Indian population which is vegetarian in nature. Chickpea acquires importance as it provides food for humans as well as for livestock. Furthermore, chickpea pod covers and seed coats can also be used as fodder. Chickpea nitrogen fixation plays an important role in maintenance of the soil fertility, particularly in the arid and low rainfall area (Roy et al., 2010).

Soil salinity is known as a major inevitable problem, especially in arid and semi-arid regions of the world and affects about 80 million hectare of arable lands (Flowers et al., 2010), 2.95 million hectare in India and 49.2 thousand hectare in Haryana and this area is expanding (Ali, 2009). Despite the high yield potential of chickpea of over $4000 \mathrm{~kg}$ per hectare (Singh, 1990). The chickpea suffer losses from salinity both in soil and water (Flowers, 2010). Studying salinity in soil or water is of importance for agriculture because it limits distribution of higher plants in certain natural habitats and induces a wide range of adverse metabolic responses in them.

Salinity causes not only physiological dehydration (water stress) in plants, but also nutrient ion imbalance (Toker et al., 2007). Salinity stress adversely affects several morphological features and physiological processes like reduction in growth, decrease in chlorophyll, ion balance, water status, photosynthesis, increase in hydrogen peroxide, which causes lipid per oxidation and consequently membrane injury, nodulation and $\mathrm{N}_{2}$-fixation (Zhu, 2001; Kukreja et al., 2005; Flowers et al., 2010). When plants are subjected to salinity, reactive oxygen species (ROS) are also generated in response to stress conditions which cause chlorophyll degradation; lipid peroxidation and electrolyte leakage are considered to be indicators of oxidative damage. Plants have evolved diverse strategies of acclimatization and avoidance to cope with adverse environment conditions. These include accumulation of compatible osmolytes, antioxidants and enzymes scavenging ROS (Ashraf and Harris, 2004). Proline and carbohydrates are accumulated in plant tissue under saline stress, and these substances subjected to contribute to osmotic adjustment and enhancing salt tolerance. 
In recent decades considerable improvements in salinity tolerance have been made in crop species with respect to morphological and physiological characters and traits affecting salinity tolerance, but there is not enough information for chickpea tolerance. Many scientists suggested that selection is more convenient and practical if the plant species possesses distinctive indicators of salt tolerance at whole plant, tissue or cellular levels. This study is designed to determine, aside from growth, the effect of salt stress on physiological and biochemical parameters in chickpea varieties exhibiting differences in salinity tolerance. Comparison of these responses could be useful in identifying differences related to the relative ability of each cultivar to cope with salinity. Results from this study can supply information on the possible potential physiological and biochemical indicators and also could allow deeper insights in to the mechanisms of tolerance to salt-induced stress.

\section{Materials and Methods}

Two chickpea (Cicer arietinum L.) genotypes CSG-8962 (salt tolerant) and HC-3 (released variety) were raised in pots filled with dune sand $[93.3 \%$ sand $+3.0 \%$ slit $+3.7 \%$ clay, saturation capacity $25 \%, \mathrm{pH} 8.2, \mathrm{ECe}_{2} 0.8 \mathrm{dS}$ $\mathrm{m}^{-1}$ at $25{ }^{\circ} \mathrm{C}, 10.3 \mathrm{mg}(\mathrm{N}) \mathrm{kg}^{-1}, 2.5 \mathrm{mg}(\mathrm{P})$ $\mathrm{kg}^{-1}, 180 \mathrm{mg}(\mathrm{K}) \mathrm{kg}^{-1}$ ] under screen house conditions in the Department of Botany and Plant Physiology, CCS Haryana Agricultural University, Hisar-125 004, India. The seeds before sowing were surface sterilized and inoculated with effective Rhizobium culture (Ca 181). The desired salinity was developed before sowing and maintains four levels (control, 2.0, 4.0 and $6.0 \mathrm{dS} \mathrm{m}^{-1}$ ) of chloride dominated salinity. The crop was supplied with an equal quality of nitrogen free nutrient solution with at regular interval of $15 \mathrm{~d}$. The chloride $\left(\mathrm{Cl}^{-}\right)$dominated salinity was prepared by using a mixture of different salts such as
$\mathrm{NaCl}, \mathrm{MgCl}_{2}, \mathrm{MgSO}_{4}$ and $\mathrm{CaCl}_{2}$ where $\mathrm{Na}: \mathrm{Ca}$ $+\mathrm{Mg}$ was in the ratio of 1:1 and $\mathrm{Ca}: \mathrm{Mg}$ in the ratio of $1: 3$, the $\mathrm{Cl}: \mathrm{SO}_{4}$ ratio was $7: 3$ on a meq basis. Sampling was done at 50-60 days after sowing (DAS).

Water potential of leaves was measured with the help of pressure chamber (Model 3005, Soil Moisture Equipment Corporation, Santa Barbara, CA, USA), between 8 AM to 10 AM. The osmotic potential ( $\Psi_{\mathrm{s}}$ ) of leaves and roots was determined with vapour pressure osmometer (Model 5100-B, Wescor, Logan, USA). The relative water content (RWC) of leaves and roots was measured according to Weatherley (1950). These measurements were made between 8 AM to 10 AM (local time) during a sunny day. Chlorophyll and carotenoid contents of leaves were estimated according to the method of Hiscox and Israelstam (1979) using dimethyl sulfoxide (DMSO). Proline of leaves and roots was estimated spectrophotometrically according to Bates et al., (1973).

Total soluble carbohydrates of leaves and roots were determined with the method of Yemm and Willis (1954). $\mathrm{Cl}^{-}$content was estimated by an ion analyser (Model L1- 126, Elico, Delhi, India) and expressed as $\mu$ moles $\mathrm{g}^{-1} \mathrm{DW} . \mathrm{SO}_{4}{ }^{2-}$ was estimated by turbidimetric method by Chesnin and Yien (1950). Sodium and potassium contents were estimated using Flame Photometer (Model CL26D, Elico, Delhi, India) and further expressed in $\mathrm{Na}^{+} / \mathrm{K}^{+}$ ratio. Photochemical efficiency / quantum yield was determined with intact plants in the field with an OS-30P Chlorophyll Flurometer (Opti-Science, Inc., Hudson, USA). Initial $\left(\mathrm{F}_{0}\right)$ and maximum $\left(\mathrm{F}_{\mathrm{m}}\right)$ fluorescence were recorded and variable fluorescence $\left(\mathrm{F}_{\mathrm{v}}\right)$, derived by subtracting $F_{o}$ from $F_{m}$. Quantum yield/ photochemical efficiency which is $\mathrm{F}_{\mathrm{v}} / \mathrm{F}_{\mathrm{m}}$ ratios were than calculated. The yield and its attributing characters were recorded at the time of harvesting. 
Data were subjected to analysis of variance (ANOVA) using online Statistical Analysis Package (OPSTAT, Computer Section, CCS Haryana Agricultural University, Hisar, Haryana, India) and treatment means were compared by the least significant differences (LSD) $(\mathrm{p}<0.05)$.

\section{Results and Discussion}

The water potential $\left(\Psi_{w}\right)$ of leaves and osmotic potential of leaves and roots decreased significantly in both the genotypes. HC-3 showed more negative values $\Psi_{w}$ of leaves i.e. from -0.47 to $-0.54 \mathrm{MPa}$ as compared to -0.45 to $-0.51 \mathrm{MPa}$ in CSG-8962, respectively. The $\Psi_{s}$ of leaves decreased from -0.75 to -1.32 in HC-3 and -0.62 to $-1.18 \mathrm{MPa}$ in CSG-8962 and -0.64 to -0.94 in $\mathrm{HC}-3$ and -0.60 to -0.87 $\mathrm{MPa}$ in roots of CSG-8962 with increase in salinity level from control to $6.0 \mathrm{dS} \mathrm{m} \mathrm{m}^{-1}$. Relative water content (RWC) of leaves decreased significantly from 7.2 to $30.7 \%$ and 4.6 to $21.9 \%$ in CSG-8962 and $\mathrm{HC}-3$ genotypes. Similarly a significant decrease in RWC was observed in both the genotypes of roots i.e. from 5.3 to $29.9 \%$ in CSG-8962 and 2.8 to $21.9 \%$ in HC-3 with increasing salinity levels from control to $6.0 \mathrm{dS} \mathrm{m} \mathrm{m}^{-1}$ (Table 1). The proposed reason for decreasing $\Psi_{s}$ is that plant adjust to physiological drought conditions caused by salinity to maintain pressure potential (Wright et al., 1997, Kumar et al., 2008). Decline in $\Psi_{s}$ can be result of either simple passive concentration of solutes due to dehydration or net accumulation of proline and total soluble carbohydrates (TSC). Similar results were reported by Sairam et al., 2002 in wheat genotypes.

Chlorophyll a, chlorophyll b, and carotenoid concentration of chickpea genotypes grown under different levels of salinity are given in figure $1(a, b, c)$ The chlorophyll ' $a$ ' decrease significantly from 1.40 to 0.870 in $\mathrm{HC}-3$ and
1.35 to $0.603 \mathrm{mg} \mathrm{g}^{-1} \mathrm{DW}$ in CSG-8962 (Figure $1 \mathrm{a}$ ), the chlorophyll ' $b$ ' from 0.613 to 0.414 in HC-3 and 0.605 to $0.354 \mathrm{mg} \mathrm{g}^{-1} \mathrm{DW}$ in CSG8962 (Figure $1 \mathrm{~b}$ ), and the carotenoid decrease significantly from 4.50 to 0.314 in $\mathrm{HC}-3$ and 0.424 to $0.225 \mathrm{mg} \mathrm{g}^{-1} \mathrm{DW}$ in CSG-8962 (Figure $1 \mathrm{c}$ ). Parida and Das (2005) suggested that decrease in chlorophyll content in response to salt stress is a general phenomenon which led to disorder in synthesizing chlorophyll and appearing chlorosis in plant. Overall the genotype HC-3 showed that less reduction in photosynthetic pigments compared to CSG-8962. Similarly in mungbean seedling, chlorophyll a, b and carotenoid contents were greatly reduced under salt stress (Zayed and Zeid, 1997-98). The quantum yield (Fv/Fm) of leaves decreased from 0.712 to 0.593 and 0.726 to 0.599 in CSG-8962 and HC-3, respectively increasing salinity levels from control to 6.0 $\mathrm{dS} \mathrm{m} \mathrm{m}^{-1}$ (Figure $1 \mathrm{~d}$ ). Hall and Rao (1999) reported that analysis of fluorescence characteristics such as quantum yield reflects the properties of the chlorophyll molecules and their interaction with the external environment and also with associated physiological processes.

The proline content of leaves was increased i.e. from 0.565 to 0.782 and 0.573 to $0.904 \mathrm{mg}$ $\mathrm{g}^{-1}$ dry weight at 50-60 DAS (Figure 2 a) in the genotypes CSG-8962 and HC-3, respectively. Similarly, the proline content of roots was found to be increased significantly in both the genotypes from 0.090 to 0.265 and 0.098 to $0.305 \mathrm{mg} \mathrm{g}^{-1} \mathrm{DW}$ in the genotypes CSG-8962 and HC-3, respectively (Figure 2 a). Accumulation of proline was more in roots than leaves as later were directly in contact with salt impregnated soil sphere. A rapid accumulation of proline under salt stress has been observed in mungbean crop (Singh et al., 1994) and chickpea (Kumar et al., 2008). 
Table.1 Changes in water potential $\Psi_{w}(-\mathrm{MPa})$, osmotic potential $\Psi_{s}(-\mathrm{MPa})$ and relative water content (RWC \%) of chickpea genotypes under different salinity levels

\begin{tabular}{|c|c|c|c|c|c|c|c|c|c|c|c|}
\hline \multirow[t]{2}{*}{ Parameters } & \multirow[t]{2}{*}{ Genotypes } & \multicolumn{10}{|c|}{ Salinity levels $\left(\mathrm{dS} \mathrm{m} \mathrm{m}^{-1}\right)$} \\
\hline & & \multicolumn{2}{|l|}{$\mathbf{0}$} & \multicolumn{2}{|l|}{2} & \multicolumn{2}{|c|}{4} & \multicolumn{2}{|l|}{6} & \multicolumn{2}{|l|}{ M } \\
\hline & & \multicolumn{10}{|c|}{ Leaves } \\
\hline \multirow{4}{*}{$\Psi_{w}$} & $\mathrm{HC}-3$ & \multicolumn{2}{|l|}{0.47} & \multicolumn{2}{|l|}{0.48} & \multicolumn{2}{|c|}{0.50} & \multicolumn{2}{|l|}{0.54} & \multicolumn{2}{|l|}{0.49} \\
\hline & CSG 8962 & \multicolumn{2}{|l|}{0.45} & \multicolumn{2}{|l|}{0.46} & \multicolumn{2}{|l|}{0.47} & \multicolumn{2}{|l|}{0.51} & \multicolumn{2}{|l|}{0.47} \\
\hline & Mean & \multicolumn{2}{|l|}{0.46} & \multicolumn{2}{|l|}{0.47} & \multicolumn{2}{|l|}{0.48} & \multicolumn{2}{|l|}{0.53} & \\
\hline & $\mathrm{CD}$ at $5 \%$ & \multicolumn{10}{|c|}{ Genotype $=0.01 ;$ Salinity $=0.02 ; \mathrm{G} \times \mathrm{S}=\mathrm{NS}$} \\
\hline \multirow{6}{*}{$\Psi_{\mathrm{s}}$} & & \multicolumn{5}{|c|}{ Leaves } & \multicolumn{5}{|c|}{ Roots } \\
\hline & & $\mathbf{0}$ & 2 & 4 & 6 & M & $\mathbf{0}$ & 2 & 4 & 6 & M \\
\hline & HC-3 & 0.75 & 1.03 & 1.15 & 1.32 & 1.06 & 0.64 & 0.74 & 0.86 & 0.94 & 0.80 \\
\hline & CSG 8962 & 0.62 & 0.93 & 1.02 & 1.18 & 0.94 & 0.60 & 0.63 & 0.80 & 0.97 & 0.73 \\
\hline & Mean & 0.68 & 0.98 & 1.09 & 1.25 & & & & & & \\
\hline & $\mathrm{CD}$ at $5 \%$ & \multicolumn{5}{|c|}{$\begin{array}{c}\text { Genotype }=0.02 ; \text { Salinity }=0.03 ; G x \\
S=N S\end{array}$} & \multicolumn{5}{|c|}{$\begin{array}{c}\text { Genotype }=0.14 ; \text { Salinity }=0.20 ; G x \\
S=0.28\end{array}$} \\
\hline \multirow{4}{*}{ RWC } & $\mathrm{HC}-3$ & 92.61 & 88.37 & 79.65 & 72.26 & 83.22 & 95.19 & 92.50 & 85.43 & 74.29 & 86.85 \\
\hline & CSG 8962 & 88.72 & 82.38 & 71.56 & 61.46 & 76.03 & 93.41 & 88.47 & 79.28 & 65.41 & 81.64 \\
\hline & Mean & 90.66 & 85.37 & 75.60 & 66.86 & & 94.30 & 90.48 & 82.36 & 69.85 & \\
\hline & $\mathrm{CD}$ at $5 \%$ & \multicolumn{5}{|c|}{$\begin{aligned} \text { Genotype }=0.27 ; \text { Salinity }=0.39 ; \mathrm{Gx} \mathrm{S} \\
=0.55\end{aligned}$} & \multicolumn{5}{|c|}{$\begin{array}{c}\text { Genotype }=1.57 ; \text { Salinity }=2.23 ; \mathrm{G} x \\
\mathrm{~S}=3.15\end{array}$} \\
\hline
\end{tabular}

Table. 2 Changes in $\mathrm{Cl}^{-}$content $\left(\mathrm{mg} \mathrm{g}^{-1} \mathrm{DW}\right), \mathrm{SO}_{4}{ }^{2-}$ content $\left(\mathrm{mg} \mathrm{g}^{-1} \mathrm{DW}\right)$ and $\mathrm{Na}^{+} / \mathrm{K}^{+}$ratio of chickpea genotypes under different salinity levels

\begin{tabular}{|c|c|c|c|c|c|c|c|c|c|c|c|}
\hline \multirow[t]{2}{*}{ Parameters } & \multirow[t]{2}{*}{ Genotypes } & \multicolumn{10}{|c|}{ Salinity levels $\left(\mathrm{dS} \mathrm{m}^{-1}\right)$} \\
\hline & & $\mathbf{0}$ & 2 & 4 & 6 & M & $\mathbf{0}$ & 2 & 4 & 6 & M \\
\hline & & \multicolumn{5}{|c|}{ Leaves } & \multicolumn{5}{|l|}{ Roots } \\
\hline \multirow{4}{*}{$\mathrm{Cl}^{-}$} & $\mathrm{HC}-3$ & 0.600 & 0.617 & 0.867 & 1.160 & 0.811 & 0.643 & 0.627 & 0.927 & 1.237 & 0.865 \\
\hline & CSG 8962 & 0.610 & 0.640 & 0.917 & 1.343 & 0.878 & 0.603 & 0.703 & 1.103 & 1.557 & 0.992 \\
\hline & Mean & 0.606 & 0.626 & 0.891 & 1.250 & & 0.623 & 0.665 & 1.028 & 1.37 & \\
\hline & $\mathrm{CD}$ at $5 \%$ & \multicolumn{5}{|c|}{$\begin{array}{c}\text { Genotype }=0.024 ; \text { Salinity }=0.034 ; \mathrm{G} \mathrm{x} \\
\mathrm{S}=0.048\end{array}$} & \multicolumn{5}{|c|}{$\begin{array}{c}\text { Genotype }=0.022 ; \text { Salinity }=0.031 \\
\text { G x S }=0.043\end{array}$} \\
\hline \multirow{4}{*}{$\mathrm{SO}_{4}{ }^{2-}$} & $\mathrm{HC}-3$ & 0.573 & 0.610 & 0.620 & 0.637 & 0.610 & 0.597 & 0.607 & 0.667 & 0.673 & 0.636 \\
\hline & CSG 8962 & 0.587 & 0.627 & 0.643 & 0.703 & 0.640 & 0.623 & 0.630 & 0.667 & 0.697 & 0.654 \\
\hline & Mean & 0.580 & 0.618 & 0.632 & 0.670 & & 0.600 & 0.610 & 0.660 & 0.680 & \\
\hline & $\mathrm{CD}$ at $5 \%$ & \multicolumn{5}{|c|}{$\begin{array}{c}\text { Genotype }=0.015 ; \text { Salinity }=0.021 ; \mathrm{G} x \\
\text { S }=\text { NS }\end{array}$} & \multicolumn{5}{|c|}{$\begin{aligned} \text { Genotype }= & 0.016 ; \text { Salinity }=0.023 \\
& \text { G x S }=\text { NS }\end{aligned}$} \\
\hline \multirow{4}{*}{$\mathrm{Na}^{+} / \mathrm{K}^{+}$ratio } & $\mathrm{HC}-3$ & 0.143 & 0.171 & 0.221 & 0.288 & 0.206 & 0.204 & 0.251 & 0.372 & 0.539 & 0.341 \\
\hline & CSG 8962 & 0.166 & 0.213 & 0.295 & 0.364 & 0.259 & 0.208 & 0.282 & 0.388 & 0.624 & 0.376 \\
\hline & Mean & 0.155 & 0.192 & 0.258 & 0.326 & & 0.206 & 0.267 & .380 & 0.582 & \\
\hline & $\mathrm{CD}$ at $5 \%$ & \multicolumn{5}{|c|}{$\begin{array}{c}\text { Genotype }=0.006 ; \text { Salinity }=0.009 ; \mathrm{G} x \\
S=0.012\end{array}$} & \multicolumn{5}{|c|}{$\begin{array}{c}\text { Genotype }=0.008 ; \text { Salinity }=0.011 \\
\text { G x S }=0.016\end{array}$} \\
\hline
\end{tabular}


Int.J.Curr.Microbiol.App.Sci (2018) 7(11): 2380-2388

Table.3 Changes in yield and its attributes of chickpea genotypes under different salinity levels

\begin{tabular}{|c|c|c|c|c|c|c|}
\hline \multirow[t]{2}{*}{ Parameters } & \multirow[t]{2}{*}{ Genotypes } & \multicolumn{5}{|c|}{ Salinity levels $\left(\mathrm{dS} \mathrm{m}^{-1}\right)$} \\
\hline & & $\mathbf{0}$ & 2 & 4 & 6 & M \\
\hline \multirow{4}{*}{ Branches plant ${ }^{-1}$} & $\mathrm{HC}-3$ & 9.00 & 8.33 & 8.00 & 6.33 & 7.91 \\
\hline & CSG-8962 & 8.00 & 7.00 & 6.6 & 5.00 & 6.91 \\
\hline & Mean & 8.50 & 8.16 & 7.33 & 5.66 & \\
\hline & $\mathrm{CD}$ at $5 \%$ & \multicolumn{5}{|c|}{ Genotype $=0.30 ;$ Salinity $=0.43 ;$ G x S $=$ NS } \\
\hline \multirow{4}{*}{ Pods plant $^{-1}$} & $\mathrm{HC}-3$ & 13.66 & 13.33 & 11.33 & 8.66 & 11.75 \\
\hline & CSG-8962 & 12.66 & 11.33 & 8.33 & 7.66 & 10.00 \\
\hline & Mean & 13.16 & 12.33 & 9.83 & 8.16 & \\
\hline & $\mathrm{CD}$ at $5 \%$ & \multicolumn{5}{|c|}{ Genotype $=0.50 ;$ Salinity $=0.71 ; \mathrm{G} \times \mathrm{S}=1.00$} \\
\hline \multirow{4}{*}{ Seeds pod ${ }^{-1}$} & $\mathrm{HC}-3$ & 1.66 & 1.33 & 1.33 & 1.33 & 1.41 \\
\hline & CSG-8962 & 1.66 & 1.30 & 1.00 & 1.00 & 1.24 \\
\hline & Mean & 1.66 & 1.31 & 1.16 & 1.16 & \\
\hline & $\mathrm{CD}$ at $5 \%$ & \multicolumn{5}{|c|}{ Genotype $=0.04 ;$ Salinity $=0.05 ;$ G x S $=0.08$} \\
\hline \multirow{4}{*}{100 seed weight (g) } & HC-3 & 29.36 & 24.72 & 15.75 & 10.97 & 20.20 \\
\hline & CSG-8962 & 13.68 & 10.82 & 8.83 & 7.47 & \\
\hline & Mean & 21.52 & 17.77 & 12.29 & 9.22 & \\
\hline & $\mathrm{CD}$ at $5 \%$ & \multicolumn{5}{|c|}{ Genotype $=0.51 ;$ Salinity $=0.72 ; \mathrm{G} \times \mathrm{S}=1.02$} \\
\hline \multirow{4}{*}{ Seed yield plant ${ }^{-1}(g)$} & HC-3 & 26.00 & 25.00 & 23.00 & 19.00 & 23.25 \\
\hline & CSG-8962 & 25.00 & 23.00 & 22.33 & 16.00 & 21.58 \\
\hline & Mean & 25.50 & 24.00 & 22.66 & 17.50 & \\
\hline & $\mathrm{CD}$ at $5 \%$ & \multicolumn{5}{|c|}{ Genotype $=0.59 ;$ Salinity $=0.84 ; \mathrm{G} \times \mathrm{S}=1.19$} \\
\hline
\end{tabular}

Fig.1 Changes in chlorophyll a (a), chlorophyll b (b), carotenoid content (c) and quantum yield (d) of chickpea genotypes under different salinity levels

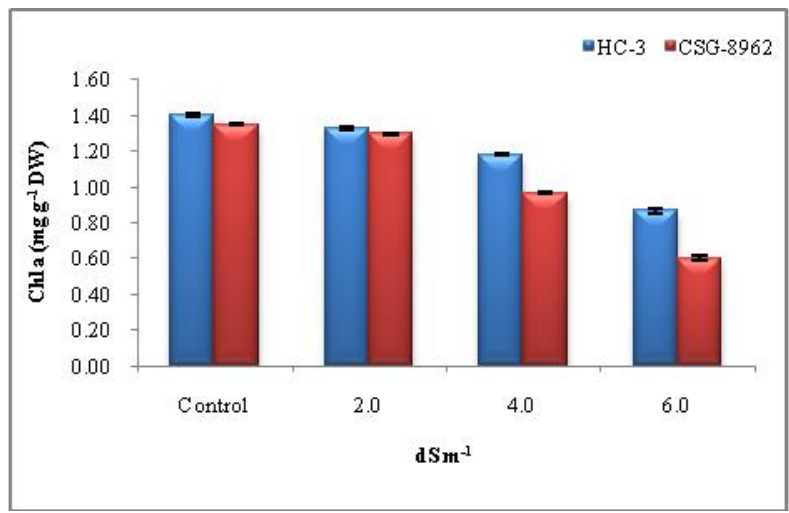

(a)

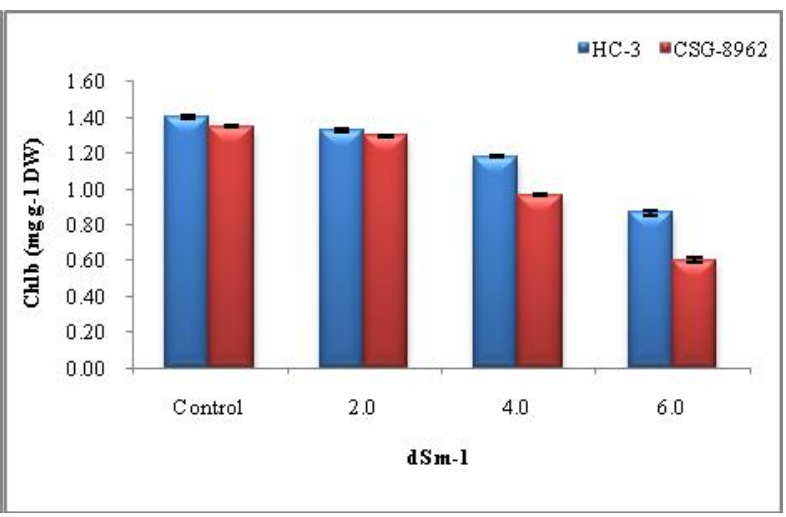

(b) 


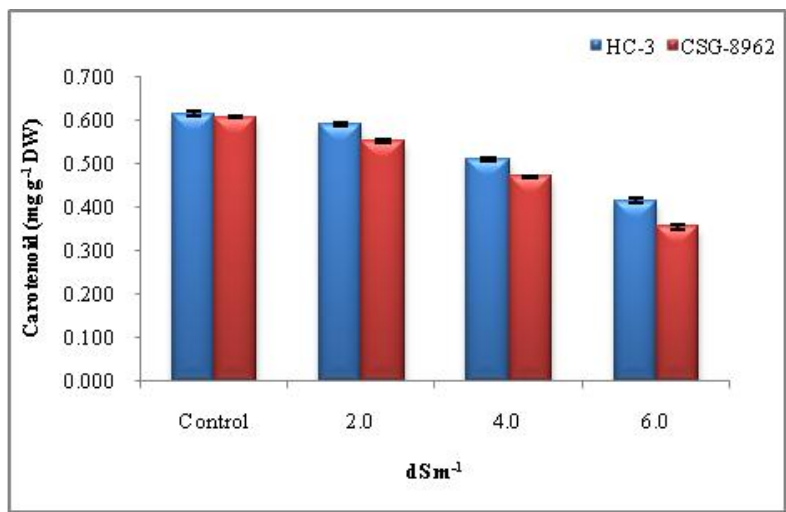

(c)

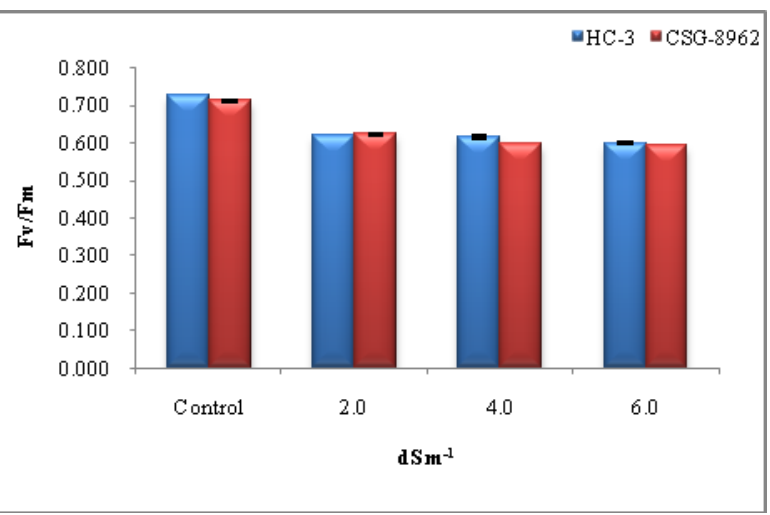

(d)

Fig.2 Changes in proline content (a) and total soluble carbohydrates (b) of chickpea genotypes under different salinity levels

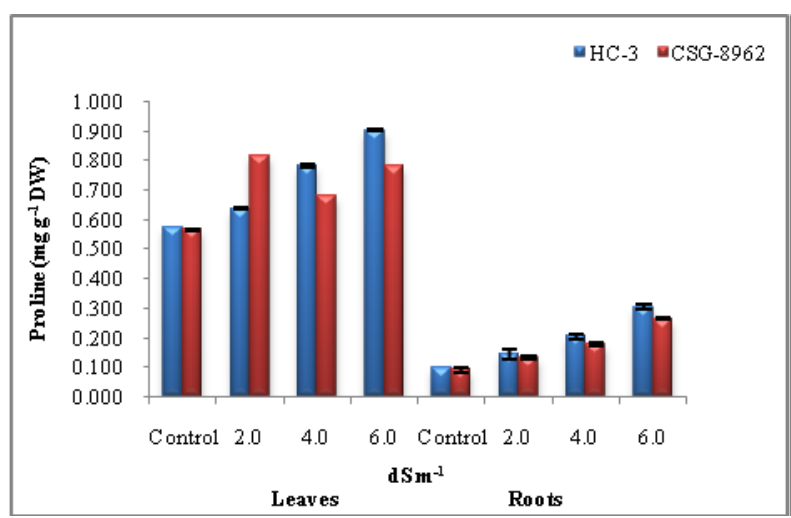

(a)

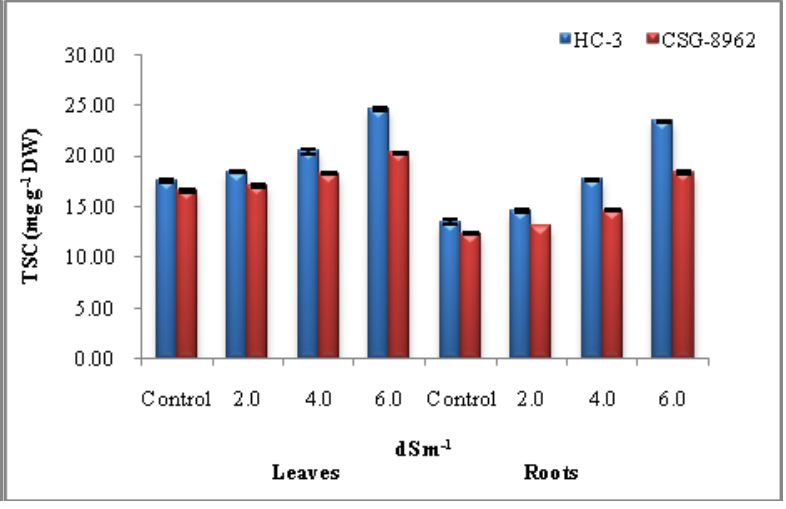

(b)
The total soluble carbohydrates of leaves increased from 16.60 to 20.24 and 17.55 to $24.56 \mathrm{mg} \mathrm{g}^{-1} \mathrm{DW}$ (Figure $2 \mathrm{~b}$ ) in the genotypes CSG-8962 and HC-3 and in roots from 12.9 to 18.4 and 13.4 to 23.4 in CSG-8962 at 5060 DAS respectively.

Similarly Tawfic (2008) also reported an increase in total soluble carbohydrates in cowpea plants grown under salt stress.

The $\mathrm{Cl}^{-}$content in leaves increased $120.1 \%$ in CSG-8962 and $93.3 \%$ in HC-3 genotype and in roots by $158.2 \%$ and $92.3 \%$ at $6.0 \mathrm{dS} \mathrm{m}$ ${ }^{1}$ salinity level in CSG-8962 and $\mathrm{HC}-3$, respectively (Table 2 ). The $\mathrm{SO}_{4}{ }^{2-}$ content was increased by $19.7 \%$ in leaves of salinised plants of CSG-8962 as compared by $11.1 \%$ in $\mathrm{HC}-3$ than their corresponding controls and similarly in roots the $\mathrm{SO}_{4}{ }^{2-}$ content increased from 1.1 to 11.8 and 1.6 to $12.7 \%$ in the genotypes CSG-8962 and HC-3, respectively.

Similar result was found that sulphate content also decreased with progressive increase in salinity level in leaves and stem but increased in roots of sea black horn (Chen et al., 2009).

Number of branches plant ${ }^{-1}$ reduced to $37.5 \%$ and $29.6 \%$ in the genotypes CSG-8962 and $\mathrm{HC}-3$, respectively, at $6.0 \mathrm{dS} \mathrm{m} \mathrm{m}^{-1}$ salinity level.

The number of pods plant ${ }^{-1}$ reduced to $39.5 \%$ and $36.6 \%$ in the genotypes CSG-8962 and $\mathrm{HC}-3$, respectively. The percent reduction in number of seeds pod $^{-1}$ was $39.7 \%$ in CSG8962 and $19.8 \%$ in HC-3. The percent 
reduction in test weight was $7.4 \%$ in CSG8962 and $10.9 \%$ in $\mathrm{HC}-3$ at $6.0 \mathrm{dS} \mathrm{m}^{-1}$.

The percent reduction in seed yield plant ${ }^{-1}$ was 27.3, 43.8 and $58.0 \%$ and 19.0, 31.5 and $52.0 \%$ in the genotypes CSG-8962 and HC-3, respectively at 2.0, 4.0 and $6.0 \mathrm{dS} \mathrm{m}^{-1}$ salinity level with respect to their control (Table 3 ).

Turner et al., (2013) also observed that saline treatment $(40 \mathrm{mM} \quad \mathrm{NaCl})$ significantly decreased the seed yield in chickpea genotypes and genotypic variation for salinity tolerance exists in chickpea.

HC-3 showed comparative better perform than CSG-8962 on the basis of various physiological traits related to plant water relations, chlorophyll, osmolyte accumulation, ionic distribution and yield attributes under saline conditions.

\section{Abbreviations}

$\mathrm{dS} \mathrm{m}^{-1}$ - DeciSiemens per metre, DAS - Days after sowing, DW - Dry weight, MPa - Mega Pascal, RWC - Relative water content, TSCTotal soluble carbohydrates, $\Psi_{\mathrm{w}}-$ Water potential, $\Psi_{\mathrm{s}}$ - Osmotic potential

\section{References}

AICRP (2014-15). All India Coordinated Research Project on Chickpea. Project Coordinator's Report. ICAR-Indian Institute of Pulses Research, Kanpur, Uttar Pradesh, India.

Ali Q (2009). Alleviation of salt stress through nutrient management. ICAR Azad Hind Store Private Limited Publisher. pp. 132157.

Arefian M, Vessal S and Bagheri A (2014). Biochemical changes and SDS-PAGE analyses of chickpea (Cicer arietinum L.) genotypes in response to salinity during the early stages of seedling growth. Journal of Biological and Environmental Science. 8(23): 99-109.
Ashraf M and Harris PJC (2004). Potential biochemical indicators of salinity tolerance in plants. Journal of Plant Science. 166: 3-16.

Bates LS, Waldren RP and Teare ID (1973). Raid determination of free proline for water stress studies. Plant and Soil. 39: 205-207.

Chen LS and Cheng, L (2009). Photosystem II is more tolerant to high temperature in apple leaves than in fruit peel. Photosynthetica.47: 112-120.

Chesnin L and Yien CH (1950). Turbidimetric determination of available sulphur. Soil Science Society of America Proceedings. 15: 149-151.

Chhabra R (1973). Kinetics of absorption of chloride and phosphorus, their interaction and effect on growth and composition of tomato plants. Ph.D. Thesis, KUL, Belgium.

Flowers TJ, Gaur PM, Gowda CLL, Krishnamurthy L, Samineni S, Siddique KHM, Turner NC, Vadez V, Varshney RK and Colmer TD (2010). Salt sensitivity in chickpea. Plant Cell and Environment. 33: 490-509.

Hall DO and Rao KK (1999). Photosynthesis.6th edition. Cambridge University press, Cambridge.

Hiscox JD and Isrealstam GF (1979). A method for the extraction of chlorophyll from leaf tissue without maceration. Canadian Journal of Botany. 57: 1332-1334.

Kukreja S, Nandwal AS, Kumar N, Sharma SK, Sharma SK, Unvi, VK and Sharma PK (2005). Plant water status, $\mathrm{H}_{2} \mathrm{O}_{2}$ scavenging enzymes, ethylene evolution and membrane integrity of Cicer arietinum roots as affected by salinity. BiologiaPlantarum. 49: 305-308.

Kumar N, Singh S, Nandwal AS, Waldia RS and Sharma MK (2008). Genotypic differences in water status, membrane integrity, ionic content, $\mathrm{N}$-fixing efficiency and dry matter of mungbean nodules under saline irrigation. Physiology and Molecular Biology of Plants. 14: 1-6. 
Parida AK and Das AB (2005). Salt tolerance and salinity effect on plants: a reviewEcotoxicology and Environmental Safety. 60: 324-349.

Roy F, Boye J and Simpson B (2010). Bioactive proteins and peptides in pulse crops: Pea, chickpea and lentil. Food Research International. 43: 432-442.

Sairam RK, Rao KV and Srivastava GC (2002). Differential responses of wheat genotypes to long term salinity stress in relation to oxidative stress, antioxidant activity and osmolytic concentration. Plant Science. 163: 1037-1046.

Singh KB (1990). Present Status and Future Prospects of Chickpea Crop Production and Improvement in the Mediterranean Countries, (Eds. M. C. Saxena, J. I. Cubero and J. Wery). Options Mediterraneennes, Serie A: Seminaires Mediterraneens, Numero 9. Zaragoza, Spain: CIHEAM. pp. 25-34.

Singh SP, Singh BB and Singh M (1994). Effect of kinetin on chlorophyll, nitrogen and proline in mungbean (Vigna radiata) under saline conditions. Indian Journal of Plant Physiology. 37: 37-39.

Tawfic KM (2008). Evaluating the use of Rhizobacterium on cowpea plants grown under salt stress. Journal of Medicinal Plants Research. 4: 26-33.

Tekeoglu M, Santra DK, Kaiser WJ and Muehlbauer FJ (2000).Ascochyta blight resistance in three chickpea recombinant inbred line populations. Crop Science. 40: 1251-56.

Toker C, Lluch C, Tejera N, Serraj R and Siddique K (2007).In Chickpea Breeding and Management. (Eds. Yadav, S.S.,
Redden, R.J., Chen, W. and Sharma, B) pp. 474-496.

Turner NC, Colmer TD, Quealy J, Pushpavalli R, Krishnamurthy L, Kaur J, Singh G, Siddique KHM and Vadez V (2013). Salinity tolerance and ion accumulation in chickpea (Cicer arietinum L.) subjected to salt stress. Plant Soil. 365: 347-361.

Vavilov NI (1926). Studies on the origin of cultivated plants. Leningrad, pp. 129-238.

Weatherley PE (1950). Studies on the water relations of the cotton plant. The field measurement of water deficit in leaves. New Phytologist. 40: 81-97.

Williams PC and Singh U (1987). The chickpea. (Eds. Saxena, M. and Singh, K.B.). CAB International, Wallingford, Oxon, United Kingdom. pp. 329-356.

Wright PR, Morgan JM and Jessop RS (1997). Turgor maintenance by osmo regulation in Brassica napus and B. juncea under field condition. Annals of Botany. 80: 313-319.

Yemm EW and Willis AJ (1954). The estimation of carbohydrates in plant extract by anthrone. Journal of Biochemistry. 57: 508-514.

Yemm EW and Willis AJ (1954). The estimation of carbohydrates in plant extract by anthrone. Journal of Biochemistry.57: 508-514.

Zayed MA and Zeid IM (1997-98). Effect of water and salt stress on growth, chlorophyll, mineral ions and organic solutes contents and enzymes activity in mungbean seedlings. Biologia Plantarum. 40: 351-356.

Zhu JK (2001). Plant salt tolerance. Trends in Plant Science.6: 66-71.

\section{How to cite this article:}

Dharamvir, Ajeev Kumar, Neeraj Kumar and Mahesh Kumar. 2018. Physiological Responses of Chickpea (Cicer arietinum L.) Genotypes to Salinity Stress. Int.J.Curr.Microbiol.App.Sci. 7(11): 2380-2388. doi: https://doi.org/10.20546/ijcmas.2018.711.269 